\title{
Evaluation of groundwater quality in central Saudi Arabia using hydrogeochemical characteristics and pollution indices
}

Talal Alharbi

King Saud University

Abdelbaset Sabry El-Sorogy ( $\sim$ elsorogyabd@yahoo.com )

King Saud University https://orcid.org/0000-0003-0283-1433

Saleh Qaysi

King Saud University

Fahad Alshehri

King Saud University

\section{Research Article}

Keywords: Groundwater quality, pollution indices, palm farms, Saudi Arabia.

Posted Date: March 18th, 2021

DOI: https://doi.org/10.21203/rs.3.rs-240928/v1

License: (c) (i) This work is licensed under a Creative Commons Attribution 4.0 International License. Read Full License 


\section{Abstract}

The groundwater quality and heavy metal contamination were evaluated in thirty palm farms, central Saudi Arabia using pollution indices, irrigation quality parameters, and multivariate statistical analyses. The results showed that the average values of TDS, $\mathrm{Ca}+, \mathrm{Na}+, \mathrm{K}+, \mathrm{Cl}-, \mathrm{SO} 42-$, and $\mathrm{F}-$ were greater than the permissible limits of the WHO standards for drinking water. The groundwater facies types were $\mathrm{Ca}-\mathrm{Na}-\mathrm{SO} 4-\mathrm{Cl}$ (23 samples), $\mathrm{Ca}-\mathrm{Cl}-\mathrm{SO} 4$, (4 samples), and Ca-SO 4 - $\mathrm{Cl}$ type (3 samples). The groundwater quality index indicated that 15 groundwater samples were of good quality and 15 were of poor quality, whereas the metal index and heavy metal pollution index indicated that all samples were categorized as slightly affected and with low pollution, respectively. The variation is attributed to the increasing average values of some ions and decreasing HMs. The dissolution/precipitation of silicates, gypsum, and carbonates, and soil leaching were the natural factors affecting groundwater chemistry, whereas higher PO 4 3- , NO $3-,, F-, P b$, and $\mathrm{Zn}$ values in some samples may be attributed to human activities from the extensive use of fertilizers and pesticides on the investigated farms.

\section{Introduction}

Groundwater is a critical resource for domestic and agricultural needs, especially in arid countries, where the geochemical processes resulting from aquifer-water interaction often control its quality in such minimal rainfall recharge (Alharbi 2018). The accumulation of heavy metals (HMs) in water resources is potentially harmful to human health, because of their accumulative characteristics, toxicity, and contamination of food sources. Therefore, the pollution of water resources with HMs has become a global problem (Hardaway et al. 2004; Sarkar et al. 2010; Alshahri and El-Taher 2018).

The thick Mesozoic and Cenozoic sedimentary rocks function as a prolific aquifer for groundwater in central Saudi Arabia (Alharbi and Zaidi 2018). Overdependence on groundwater resources, especially in arid countries, often leads to decreased groundwater levels and deteriorates its quality (Alharbi 2018). The rapid population growth in and extension of agricultural activities around Saudi Arabia have increased the need for freshwater resources (Khanfar 2008; Al-Hammad and Abd El-Salam 2016). Saudi Arabia is the second-largest producer of the date palm (Sueleman 2014; Salama et al. 2019). The Al Uyaynah-Al Jubailah region (Fig. 1) is located 40-55 km northwest of Riyadh, inside the narrow, dry riverbed of Wadi Hanifa, which continues southwards through Dir'iyyah and Riyadh.

The Al Uyaynah-Al Jubailah region has many agricultural farms producing several types of dates, leafy green plants (e.g., lettuce, arugula, and radish), vegetables (e.g., pepper, eggplant, tomato, watermelon, onion, and potato), and fruits (e.g., citrus, orange, pomegranate, lemon, and grapes). As groundwater is an important source of HMs for these plants and can reach humans directly or indirectly, this study evaluates the groundwater quality and HM contamination in some palm farms in central Saudi Arabia in the Al Uyaynah-Al Jubailah region and documents the possible sources of contamination, using hydrogeochemical characteristics, pollution indices, and multivariate analyses. 


\section{Methods And Materials}

A total of 30 groundwater samples were collected from 25 to 100 m-deep wells in Al Uyaynah-Al Jubailah farms, central Saudi Arabia (Fig. 1). Samples were collected in high-density polyethylene sampling bottles that were washed with $5 \%$ nitric acid and rinsed with distilled water (Salifu et al. 2015). Geologically, the carbonates of the Upper Jurassic Hanifa, Jubaila, and Arab formations and Quaternary sediments dominate the study area (Al Husseini and Mathews 2005; Hussein et al. 2012). The Hanifa Formation consists of a lower muddy carbonate unit and an upper stromatoporoid and lagoonal carbonate unit, and disconformably overlies the Tuwaiq Mountain Formation. The Jubaila Formation consists of moderately deep marine carbonates overlain by a shallow marine stromatoporoid-associated assemblage and disconformably lies on the Hanifa Formation (Power et al. 1966; Hughes 2009). Twenty samples were collected from wells drilled in Quaternary sediments, nine in Jubaila limestone, and one in the Hanifa Formation (Fig. 2). The hydrogeochemical parameters ( $\mathrm{pH}$, electrical conductivity (EC), and TDS), ions $\left(\mathrm{SiO}_{2}, \mathrm{Cl}^{-}, \mathrm{NO}_{3}{ }^{-}, \mathrm{F}^{-}, \mathrm{PO}_{4}{ }^{3-}, \mathrm{SO}_{4}{ }^{2-}\right.$, and $\mathrm{HCO}_{3}{ }^{-}, \mathrm{Mg}^{2+}, \mathrm{Ca}^{2+}, \mathrm{K}^{+}$, and $\left.\mathrm{Na}^{+}\right)$, and $\mathrm{HMs}(\mathrm{Hg}, \mathrm{Al}, \mathrm{Sb}, \mathrm{Cu}, \mathrm{Cr}, \mathrm{B}, \mathrm{Pb}$, $\mathrm{Ni}, \mathrm{Se}, \mathrm{Cd}, \mathrm{As}, \mathrm{Zn}$ ) were analyzed in the laboratories of King Saud University. The hydrogen ion concentration $(\mathrm{pH})$ and EC were measured using $\mathrm{pH}$ and EC meters, respectively. Sodium $\left(\mathrm{Na}^{+}\right)$, potassium $\left(\mathrm{K}^{+}\right)$, calcium $\left(\mathrm{Ca}^{2+}\right)$, and magnesium $\left(\mathrm{Mg}^{2+}\right)$ were determined using an atomic absorption spectrophotometer. Bicarbonate $\left(\mathrm{HCO}_{3}{ }^{-}\right)$and chloride $\left(\mathrm{Cl}^{-}\right)$were analyzed using volumetric methods. Sulfate $\left(\mathrm{SO}_{4}{ }^{2-}\right)$ was estimated using colorimetric and turbidimetric methods. Nitrate $\left(\mathrm{NO}_{3}{ }^{-}\right)$was measured using an ultraviolet-visible spectrophotometer. $\mathrm{F}^{-}$was determined using a fluoride-selective electrode. HMs were determined using an inductively coupled plasma-mass spectrometer.

The Piper plot was prepared to determine the groundwater facies. The groundwater quality index (GWQI), heavy metal pollution index (HPI), and metal index (MI) were used as pollution indices to document water quality. The status of groundwater for irrigation was measured using the sodium percentage $(\mathrm{Na} \%)$, Kelly's ratio (KR), salinity hazard (EC), and sodium adsorption ratio (SAR) (Richards, 1954; Doneen, 1964; Kelly, 1963; Raghunath, 1987). Tables 1 and 2 show the procedures and classification of these indices and parameters. Supplementary Table 1 shows the coordinates of groundwater boreholes (samples), hydrogeochemical parameters, major anions, major cations, and HMs. Statistical analyses were conducted using SPSS software. Principal component analysis (PCA), Pearson's correlation coefficients, and hierarchical cluster analysis (HCA; Q and R-modes) were used to identify the possible sources of HMs in the groundwater samples investigated (Alfaifi et al. 2021; Alshehri et al. 2021).

\section{Results And Discussion}

\section{Hydrogeochemical characteristics}

Table 3 shows the hydrogeochemical dataset. The groundwater $\mathrm{pH}$ ranges from 6.5 (sample 25) to 7.8 (sample 21), with an average of 7.3, implying slightly basic to slightly acidic waters, and falls within the standards prescribed for drinking water (WHO 2014). In assessing the groundwater quality for irrigation, 
TDS is a critical parameter (Salifu et al. 2015), varying from $1,088 \mathrm{mg} / \mathrm{l}$ in sample 25 to $3,815 \mathrm{mg} / \mathrm{l}$ in sample 14, with an average of $2,334 \mathrm{mg} / \mathrm{l}$, indicating values greater than the acceptable limits $(1,000$ $\mathrm{mg} / \mathrm{l}$ ) of the World Health Organization (WHO 2011). Regarding irrigation criteria (Ayers and Westcott 1985; UCCC 1974), 8 samples were categorized as slight to moderate (TDS $=450-2,000 \mathrm{mg} / \mathrm{l}$ ) and 20 samples were severe (TDS $>2,000 \mathrm{mg} / \mathrm{l}$ ). In drinking water, TDS higher than $500 \mathrm{mg} / \mathrm{l}$ could cause gastrointestinal infections in consumers (Dar et al. 2011; Gnanachandrasamy et al. 2018).

$\mathrm{Ca}^{2+}$ was the most abundant cation (average $443 \mathrm{mg} / \mathrm{l}$ ), followed by $\mathrm{Na}^{+}$(average $236 \mathrm{mg} / \mathrm{l}$ ), $\mathrm{K}^{+}$(average $42 \mathrm{mg} / \mathrm{l})$, and $\mathrm{Mg}^{2+}$ (average $28 \mathrm{mg} / \mathrm{l}$ ). The anions were dominated by $\mathrm{SO}_{4}{ }^{2-}$ (average $\left.1,016 \mathrm{mg} / \mathrm{l}\right)$, followed by $\mathrm{Cl}^{-}$(average $456 \mathrm{mg} / \mathrm{l}$ ), $\mathrm{HCO}_{3}{ }^{-}$(average $100 \mathrm{mg} / \mathrm{l}$ ), $\mathrm{NO}_{3}{ }^{-}$(average $14 \mathrm{mg} / \mathrm{l}$ ), $\mathrm{F}^{-}$(average 1.65 $\mu \mathrm{g} / \mathrm{l}$ ), and $\mathrm{PO}_{4}{ }^{3-}$ (average $0.0219 \mathrm{mg} / \mathrm{l}$ ). The average values of $\mathrm{Ca}^{+}, \mathrm{Na}^{+}, \mathrm{K}^{+}, \mathrm{Cl}^{-}, \mathrm{SO}_{4}{ }^{2-}$, and $\mathrm{F}^{-}$were greater than the permissible limits of WHO standards for drinking water (Table 2). The higher values of these cations and anions could be attributed to the ion exchange reactions or silicate weathering ( $\mathrm{Li}$ et al. 2016a).

The saturation indices of halite, dolomite, anhydrite, gypsum, calcite, and aragonite were negative (Supplementary Table 1, Fig. 3), indicating undersaturated conditions regarding the capacity of groundwater to dissolve more minerals (Yidana et al. 2010). Some gypsum and calcite samples were almost close to the saturation phase because of the prolonged interaction of groundwater with carbonate aquifers and gypsiferous layers (Deutsch and Siegel 1997). All groundwater samples fell within the Cadominant type on the cationic triangle, whereas $90 \%$ fell within the $\mathrm{SO}_{4}$-dominant type, $4 \%$ within the $\mathrm{Cl}$ dominant type, and $6 \%$ within the nondominant type on the anionic triangle (Fig. 4). $\mathrm{SO}_{4}{ }^{2-}, \mathrm{Ca}^{2+}, \mathrm{Cl}^{-}$, and $\mathrm{Na}^{+}$were the most dominant ions, and based on their dominance, the groundwater facies were classified into three types (Fig. 4): $\mathrm{Ca}-\mathrm{Na}-\mathrm{SO}_{4}-\mathrm{Cl}$ (23 samples), $\mathrm{Ca}-\mathrm{Cl}-\mathrm{SO}_{4}$, (4 samples), and $\mathrm{Ca}-\mathrm{SO}_{4}-\mathrm{Cl}(3$ samples), indicating carbonates and gypsum dissolution/precipitation influences (Kumar, 2014).

\section{Irrigation water quality}

The palm forms in the Al Uyaynah-Al Jubailah region depend primarily on groundwater for irrigation; therefore, it is important to evaluate the quality and suitability of groundwater for agricultural use. $\mathrm{Na} \%$, SAR, PI, KR, and MR were used as parameters for this evaluation (Table 2, Supplementary Table 2). The $\mathrm{Na} \%$ is considered an indicator of the soluble sodium content that reacts with the soil to decrease permeability (Janardhana Raju et al. 1992). Values of $\mathrm{Na} \%$ varied from $8.21 \%$ to $47.63 \%$, with an average of $28.97 \%$. Six samples were excellent, 21 were good, and three were in the permissible range, implying that the groundwater is suitable for irrigation.

The SAR ranged from 3.29 to 32.49 , with an average of 14.95 . The groundwater samples were classified as excellent for irrigation (13 samples), good for irrigation (4 samples), doubtful for irrigation (11 samples), and unsuitable (13 and 14). The average value of $\mathrm{Na}^{+}(235.59 \mathrm{mg} / \mathrm{l})$ was greater than the permissible limit of WHO standards (2011) for drinking water (200 mg/l). Samples 13 and 14 were of the 
$\mathrm{Ca}-\mathrm{Na}-\mathrm{SO}_{4}-\mathrm{Cl}$ facies type and had higher $\mathrm{Na}^{+}$values. On the Wilcox diagram, most SAR values were within the S1 class and few within the S2 class, and are of low to medium hazard (Fig. 5).

The EC values ranged from 1,554 to $5,450 \mu \mathrm{S} / \mathrm{cm}$, with an average of $3,334 \mu \mathrm{S} / \mathrm{cm}$. Four samples were within permissible limits for irrigation, seven were doubtful for irrigation, and 19 were unsuitable for irrigation. On the Wilcox diagram, most EC values fell within the C4 (very high) and few fell within the C3 (high) salinity zones (Fig. 4), which could be attributed to the reverse ion exchange and lack of recent groundwater recharge (Alharbi 2018). The KR values ranged from 0.09 to 0.93 , with an average of 0.48 (Supplementary Table 2). All groundwater samples were safe for irrigation (KR $\otimes 1)$. Moreover, the MR in the study area varied from $2.88 \%$ to $9.96 \%$, with an average of $6.27 \%$, indicating that the samples investigated were suitable for irrigation (MR $₫ 50 \%$ ).

\section{HM concentrations and pollution indices}

The HM levels in groundwater samples were compared with the maximum allowable concentration of the WHO $(2011,2014)$. B was the abundant HM (average $51.77 \mu \mathrm{g} / \mathrm{l}$ ), followed by $\mathrm{Zn}$ (average $13.89 \mu \mathrm{g} / \mathrm{l})$, Se (average $10.76 \mu \mathrm{g} / \mathrm{l}), \mathrm{Cr}$ (average $2.48 \mu \mathrm{g} / \mathrm{l}$ ), Cu (average $1.47 \mu \mathrm{g} / \mathrm{l}$ ), Pb (average $1.37 \mu \mathrm{g} / \mathrm{l}), \mathrm{Al}$ (average $1.34 \mu \mathrm{g} / \mathrm{l}$ ), As (average $0.92 \mu \mathrm{g} / \mathrm{l}$ ), Co (average $0.59 \mu \mathrm{g} / \mathrm{l})$, Cd (average $0.57 \mu \mathrm{g} / \mathrm{l})$, Ni (average $0.44 \mu \mathrm{g} / \mathrm{l}$ ), $\mathrm{Hg}$ (average $0.07 \mu \mathrm{g} / \mathrm{l}$ ), and $\mathrm{Sb}$ (average $0.007 \mu \mathrm{g} / \mathrm{l}$ ). The average values of these HMs were less than the permissible limits of WHO standards for drinking water (Table 3). The GWQI is a mathematical application transferring large water quality data into a single number, indicating the suitability of water for drinking (Patel and Vadodaria 2015; Sahu and Sikdar 2008). It varied from 53.64 in sample 25 to 145.05 in sample 14 (Supplementary Table 2). Fifteen samples (50\%) were of good quality (GWQI = 50100 ) and the remaining half were categorized as poor-quality samples (GWQI $=100.1-200)$. The lowest values of TDS, EC, $\mathrm{Ca}^{2+}, \mathrm{Mg}^{2+}, \mathrm{Na}^{+}, \mathrm{Cl}^{-}, \mathrm{SO}_{4}{ }^{2-}, \mathrm{B}, \mathrm{Ba}, \mathrm{Cd}, \mathrm{Ni}, \mathrm{Se}, \mathrm{Hg}, \mathrm{Pb}$, and $\mathrm{Sb}$ characterize the goodquality samples.

The MI helps to evaluate the overall quality of drinking water quickly and considers possible additive effects of HMs on human health (Enaam Abdullah 2013; Rezaei et al. 2017). The MI values ranged from 1.03 in sample 23 to 1.52 in sample 1, with an average of 1.22 (Supplementary Table 2). All groundwater samples in the study area were categorized as slightly affected $(\mathrm{MI}=1.0-2.0)$. The HPI is a powerful tool used to rank the composite influence of individual HMs on the overall water quality (Rizwan et al. 2011; Sirajudeen et al. 2014; Rezaei et al. 2017). In the study area, HPI values ranged from 7.05 in sample 6 to 17.51 in sample 1, with an average of 11.89 (Supplementary Table 2). As for the $\mathrm{Ml}$, all samples were classified as low pollution ( $\mathrm{HPI}<45)$, which is attributed to the lower average levels of HMs than the permissible WHO standard limits.

\section{Possible sources of ions and HMs}

Q-mode HCA classifies the 30 groundwater samples into clusters based on TDS and ion levels (Fig. 6). Cluster 1 includes samples $1-4,6-9,11,16-19,21,23$, and 25, which had the lowest levels of TDS, $\mathrm{Na}^{+}$, 
and $\mathrm{SO}_{4}{ }^{2-}$ (sample 25), $\mathrm{Ca}^{2+}$ and $\mathrm{Cl}^{-}$(sample 7), $\mathrm{HCO}_{3}{ }^{-}$(sample 9), $\mathrm{SO}_{2}$ (sample 11), $\mathrm{PO}_{4}{ }^{3-}$ (sample 17), and $\mathrm{NO}_{3}{ }^{-}$(sample 23). Cluster 2 includes samples $5,10,12-15,20,22,24$, and $26-30$, which had the highest values of TDS, $\mathrm{Mg}^{2+}, \mathrm{SO}_{4}{ }^{2-}$, and $\mathrm{Na}^{+}$(sample 14), $\mathrm{F}^{-}$(sample 28), $\mathrm{Cl}^{-}$(sample 30), $\mathrm{PO}_{4}{ }^{3-}$, and $\mathrm{SO}_{2}$ (sample 29). From the field survey, most samples of cluster 2 are from farms cultivated with orange, pomegranate, lemon, and leafy green plants (e.g., lettuce, arugula, and radish), with or without date palms. Extensive and repeated irrigation of such plant types could dissolve cations and anions through rock-water interactions (Kumar 2014), and increase their values in the samples investigated. However, increasing $\mathrm{PO}_{4}{ }^{3-}$ and $\mathrm{NO}_{3}{ }^{-}$could be attributed to the extensive use of fertilizers and pesticides (Alshahri and El-Taher 2018). The high vertical permeability of Quaternary loss could facilitate the vertical transport of contaminants into groundwater (Su et al. 2017). For drinking water, 18 groundwater samples had $\mathrm{F}^{-}$levels greater than the WHO permissible limit (2011) $(1.5 \mathrm{mg} / \mathrm{l})$. The possible $\mathrm{F}^{-}$sources are the leaching of minerals rich in $\mathrm{F}^{-}$, industrial emissions, and the extensive use of phosphatic fertilizers (Aswathanarayana et al. 1985; Dissanayake and Chandrajith 2009).

R-mode HCA classifies the hydrogeochemical parameters into two clusters (Fig. 7). The first cluster includes EC and the second cluster includes the remaining hydrogeochemical parameters and HMs. EC showed a significant correlation with TDS, $\mathrm{Ca}^{2+}, \mathrm{Na}^{+}, \mathrm{Cl}^{-}$, and $\mathrm{SO}_{4}{ }^{2-}$, indicating a similar origin (Supplementary Table 3). $\mathrm{Ca}^{2+}$ is correlated positively with $\mathrm{Na}^{+}, \mathrm{Cl}^{-}$, and $\mathrm{SO}_{4}{ }^{2-}$, indicating that the dissolution of gypsum is a possible source of the ion levels in groundwater ( $\mathrm{Li}$ et al. 2016a; Zhang et al. 2018b; Wu 2020). Moreover, a strong positive correlation exists between $\mathrm{SO}_{4}{ }^{2-}$ and $\mathrm{Ca}^{2+}, \mathrm{Mg}^{2+}, \mathrm{Na}^{+}$, and $\mathrm{Cl}^{-}$, implying a common source of these ions (Alfaifi et al. 2021). A positive correlation exists between $\mathrm{No}_{3}{ }^{-}$and $\mathrm{HCO}_{3}{ }^{-}$, indicating anthropogenic factors, especially agricultural activities, which are controlled enhanced weathering (Adimalla and Li 2018).

PCA was performed to document the possible sources of hydrogeochemical parameters and HMs in groundwater (Wen et al. 2019). Nine principal components accounted for $23.08 \%, 13.39 \%, 8.60 \%, 7.97 \%$, $7.15 \%, 6.76 \%, 5.77 \%, 4.66 \%$, and $4.21 \%$ of the total variance (Table 4). PC1 showed a strong association with $\mathrm{EC}, \mathrm{TDS}, \mathrm{Ca}^{2+}, \mathrm{Mg}^{2+}, \mathrm{Na}^{+}, \mathrm{Cl}^{-}$, and $\mathrm{SO}_{4}{ }^{2-}$, reflecting a natural process of the dissolution/precipitation of silicates, gypsum, and carbonates (Rezaei et al. 2017; Wu 2020). PC3 showed a strong association with NO3- and $\mathrm{Pb}$, attributed to an anthropogenic reason because of the excessive use of fertilizers and pesticides (Li et al. 2018, 2019). PC4 had high loadings for Pb and Zn, indicating soil leaching that could originate from fertilizer and pesticide use (Kukrer and Mutlu 2019; Wen et al. 2019). PC5 showed a strong association with $\mathrm{B}, \mathrm{Cd}$, and $\mathrm{Hg}$, which could be influenced by mixed anthropogenic and natural sources. PC6 had high loadings for Ni and Sb, and PC8 had high loadings for Se.

\section{Conclusions}

This study used hydrogeochemical characteristics, pollution indices, irrigation quality parameters, and multivariate statistical analyses to evaluate the groundwater quality and $\mathrm{HM}$ contamination in some 
palm farms in central Saudi Arabia. The following findings were obtained:

1. The average values of TDS, $\mathrm{Ca}^{+}, \mathrm{Na}^{+}, \mathrm{K}^{+}, \mathrm{Cl}^{-}, \mathrm{SO}_{4}{ }^{2-}$, and $\mathrm{F}^{-}$were higher than the permissible limits of WHO standards for drinking water. The principal mineral phase saturation indices were negative, indicating undersaturated conditions regarding the capacity of groundwater to dissolve more minerals.

2. The most dominant ions, in order, were $\mathrm{SO}_{4}{ }^{2-}, \mathrm{Ca}^{2+}, \mathrm{Cl}^{-}$, and $\mathrm{Na}^{+}$. According to their dominance, groundwater facies types in the study area were $\mathrm{Ca}-\mathrm{Na}-\mathrm{SO}_{4}-\mathrm{Cl}$ (23 samples), $\mathrm{Ca}-\mathrm{Cl}-\mathrm{SO}_{4},(4$ samples), and $\mathrm{Ca}-\mathrm{SO}_{4}-\mathrm{Cl}$ (3 samples), indicating carbonates and gypsum dissolution/precipitation influences.

3. The irrigation quality parameters ( $\mathrm{Na} \%, \mathrm{SAR}, \mathrm{KR}$, and MR) indicated the suitability of most samples for irrigation. However, the unsuitability of most samples for irrigation, based on EC values, could be attributed to the reverse ion exchange and lack of recent groundwater recharge.

4. The average $\mathrm{HM}$ values were lower than the permissible limits of WHO standards for drinking water. The GWQI indicated that half of the groundwater samples were of good quality and half of poor quality. The MI and HPI indicated that all samples were classified as slightly affected and with low pollution, respectively, attributed to increasing values of TDS, $\mathrm{Ca}^{+}, \mathrm{Na}^{+}, \mathrm{K}^{+}, \mathrm{Cl}^{-}, \mathrm{SO}_{4}{ }^{2-}$, and $\mathrm{F}^{-}$, and decreasing HM values.

5. Extensive and repeated irrigation could increase ion levels in general. Moreover, increasing $\mathrm{PO}_{4}{ }^{3-}$, $\mathrm{NO}_{3}{ }^{-}, \mathrm{F}^{-}, \mathrm{Pb}$, and $\mathrm{Zn}$ concentrations in some samples could be attributed to the extensive use of fertilizers and pesticides in the farms.

\section{Declarations}

Author Contribution All authorship (Talal Alharbi, Abdelbaset S. El-Sorogy, Saleh Qaysi, Fahad Alshehri) contributed in all parts of the manuscript.

Funding The authors extend their appreciation to the Deanship of Scientific Research at King Saud University for funding this work through the Research Group No. (RG-1439-031).

Data availability All data generated or analyzed during this study are included in this published article and its supplementary information file.

\section{Declarations}

Ethical approval and consent to participate Not applicable, ethical committee does not require permission to work on collection specimens

Consent for publication Not applicable

Competing interests The authors declare no competing interests. 


\section{References}

Adimalla N, Li P (2019) Occurrence, health risks and geochemical mechanisms of fluoride and nitrate in groundwater of the rock-dominant semi-arid region, Telangana state, India. Hum Ecol Risk Assess 25 (12): 81-103.

Al Husseini MI, Mathews R (2006) Stratigraphic note: orbital calibration of the Arabian plate second order sequence stratigraphy. GeoArabia 11 (3): 161-170.

Alam F (2014) Evaluation of hydrogeochemical parameters of groundwater for suitability of domestic and irrigational purposes: a case study from central Ganga Plain, India. Arab J Geosci 7 (10): 41214131.

Alfaifi, H., El-Sorogy, A.S., Qaysi, S., Kahal, A., Almadani, S., Alshehri, F., Zaidi, F.K., 2021. Evaluation of heavy metal contamination and groundwater quality along the Red Sea coast, southern Saudi Arabia. Mar Poll Bull https://doi.org/10.1016/j.marpolbul.2021.111975

Al-Hammad BA, Abd El-Salam MM (2016) Evaluation of heavy metal pollution in water wells and soil using common leafy green plant indicators in the Al-Kharj region, Saudi Arabia. Environ Monit Assess 188 (6): 324.

Alharbi TG (2018) Identification of hydrogeochemical processes and their influence on groundwater quality for drinking and agricultural usage in Wadi Nisah, Central Saudi Arabia. Arab J Geosci 11 (13): 359.

Alharbi TG, Zaidi FK (2018) Hydrochemical classification and multivariate statistical analysis of groundwater from Wadi Sahba Area in Central Saudi Arabia. Arab J Geosci 11 (20): 643.

Alshahri F, El-Taher A (2018) Assessment of heavy and trace metals in surface soil nearby an oil refinery, Saudi Arabia, using geoaccumulation and pollution indices. Arch Environ Contam Toxicol 75 (3): 390401.

Aswathanarayana U, Lahermo P, Malisa E, Nanyaro JT (1985) High fluoride waters in an endemic fluorosis area in northern Tanzania. in proceedings of the 1st international symposium on geochemistry and health monograph series. Environ. Geochem Health Thornton I, Ed: 243-249.

Ayers RS, Westcott DW (1985) Water quality for agriculture (No. 29); Food and Agriculture Organization of the United Nations: Rome, Italy.

Bodrud-Doza Md, Islam ARMT, Ahmed F, Das S, Saha N, Rahman MS (2016) Characterization of groundwater quality using water evaluation indices, multivariate statistics and geostatistics in central Bangladesh. Water Sci 30 (1): 19-40. 
Dar IA, Sankar K, Shafi T, Dar MA (2011) Investigation of groundwater quality in Hardrock Terrain using geoinformation system. Environ Monit Assess 176 (1-4): 575-595.

Deutsch WJ, Siegel R (1997) Groundwater geochemistry: Fundamentals and applications to contamination; CRC Press: Boca Raton.

Dissanayake CB, Chandrajith R (2009) Introduction to medical geology, focus on tropical environments; Springer-Verlag: Berlin Heidelberg, 297 pp.

Doneen LD (1964) Notes on water quality in agriculture published as a water science and engineering; Department of water science and engineering, University of California, paper 4001.

Enaam Abdullah J (2013) Quality assessment for Shatt Al-Arab river using heavy metal pollution index and metal index. Environ Earth Sci 3 (5): 114.

Fipps G (2003) Irrigation water quality standards and salinity management strategies. texas agricultural extension service, Texas A \& M University System; College Station: TX. B-1667, 4-03, pp 1-19.

Gnanachandrasamy G, Dushiyanthan C, Rajakumar TJ, Zhou Y (2018) Assessment of hydrogeochemical characteristics of groundwater in the lower Vellar River Basin: using geographical information system (GIS) and water quality index (WQI). Environ Dev Sustainability DOI 10.1007/s10668-018-0219-7.

Hardaway C, Sneddon J, Beck JN (2004) Determination of metals in crude oil by Atomic Spectroscopy. Anal Lett 37 (14): 2881-2899.

Hughes GW, Al-Khaled M, Varol O (2009) Oxfordian biofacies and paleoenvironments of Saudi Arabia 6: 47-60.

Hussein MT, Al Yousif MM, Awad HS (2012) Potentiality of secondary aquifers in Saudi Arabia: evaluation of groundwater quality in Jubaila limestone. Int J Geosci 3: 71-80.

Janardhana Raju N, Reddy TVK, Kotaiah BPT (1992) A study on seasonal variations of ground water quality in Upper Gunjanaeru River Basin, Cuddapah District, Andhra Pradesh. Fresenius Environ Bull 1: 98-103.

Kelley WP (1963) Use of saline irrigation water. Soil Sci 95 (6): 385-391.

Khanfar AR (2008) Groundwater investigation in Bel-Ahmar, Assir, Kingdom of Saudi Arabia. Saudi J Biol Sci 15: 289-296.

Kükrer S, Mutlu E (2019) Assessment of surface water quality using water quality index and multivariate statistical analyses in Sarayduzu Dam Lake, Turkey. Environ Monit Assess 191 (2): 71.

Kumar PJS (2014) Evolution of groundwater chemistry in and around Vaniyambadi industrial area: Differentiating the natural and anthropogenic sources of contamination. Geochemistry 74 (4): 641-651. 
Li P, Qian H (2018b) Water resource development and protection in loess areas of the world: A summary to the thematic issue of water in loess. Environ Earth Sci 77 (24): 796.

Li P, Wu J (2019a) Sustainable living with risks: meeting the challenges. Hum Ecol Risk Assess 25 (1-2), 1-10 DOI 10.1080/10807039.2019.1584030.

Li P, Wu J, Qian H (2016a) Hydrochemical appraisal of groundwater quality for drinking and irrigation purposes and the major influencing factors: A case study in and around Hua County, China. Arab J Geosci 9 (1): 15.

Patel YS, Vadodaria GP (2015) Groundwater quality assessment using water quality index. hydro. international, 20th international conference on hydraulics, water resources and river engineering, Roorkee, India.

Powers RW, Ramirez LF, Redmond CD, Elberg ELJR (1966) Geology of the Arabian peninsula, sedimentary geology of Saudi Arabia. U.S. Geol Surv Prof Pap 560 (D), 147 pp.

Raghunath HM (1987) Groundwater. Wiley Eastern Ltd. New Delhi, pp 344-369.

Rezaei A, Hassani H, Jabbari N (2019) Evaluation of groundwater quality and assessment of pollution indices for heavy metals in north of Isfahan Province, Iran. Sustain. Water Resour Manag 5 (2): 491-512.

Richards LA (1954) Diagnosis and improvement of saline and alkali soils. In. Soil science; United States Department of Agriculture: Washington, DC 78 (2).

Rizwan R, Gurdeep S, Manish Kumar J (2011) Application of heavy metal pollution index for ground water quality assessment in Angul District of Orissa, India. Int. J Res Chem Environ 1 (2): 118-122.

Sahu P, Sikdar PK (2008) Hydrochemical Framework of the Aquifer in and Around East Kolkata Wetlands, West Bengal, India. Environ Geol 55 (4): 823-835.

Salama KhF, Randhawa MA, Al Mulla AA, Labib OA (2019) Heavy metals in some date palm fruit cultivars in Saudi Arabia and their health risk assessment. Int J Food Prop 22 (1): 1684-1692.

Salifu M, Aidoo F, Hayford MS, Adomako D, Asare E (2017) Evaluating the suitability of groundwater for irrigational purposes in some selected districts of the upper west region of Ghana. Appl Water Sci 7 (2): 653-662.

Sarkar S, Ghosh PB, Sil AK, Saha T (2011) Heavy Metal Pollution Assessment Through Comparison of Different Indices in Sewage-Fed Fishery Pond Sediments at East Kolkata Wetland, India. Environ Earth Sci 63 (5): 915-924.

Sirajudeen J, Arul Manikandan S, Manivel V (2014) Heavy metal pollution index of ground water of Fathima Nagar area near Uyyakondan Channel, Tiruchirapalli District, Tamil Nadu, India. World J Pharm 
Sci 4 (1): 967-975.

Su K, Zhou Y, Wu H, Shi Ch, Zhou L (2017) An Analytical method for groundwater inflow into a drained circular tunnel. Groundwater 55 (5): 712-721.

Suleman NM (2014) Spectroscopic determination of some trace elements as pollutants in fruit dates palm and africultural soil at Zilfı Province. J Anal Chem 2 (3): 11-16.

UCCC (University of California Committee of Consultants) (1974) Guidelines for interpretations of water quality for irrigation; University of California Committee of Consultants: CA.

Wen X, Lu J, Wu J, Lin Y, Luo Y (2019) Influence of coastal groundwater salinization on the distribution and risks of heavy metals. Sci. Total Environ 652: 267-277.

World Health Organization (WHO) (2011) Guidelines for drinking water quality, 4th ed; Geneva, Switzerland.

World Health Organization (WHO) (2014) Guidelines for drinking-water quality; (3rd ed., Vol. 1, p. 515). Geneva, Recommendations.

Wu J, Li P, Wang D, Ren X, Wei M (2020) Statistical and multivariate statistical techniques to trace the sources and affecting factors of groundwater pollution in a rapidly growing city on the Chinese Loess Plateau. Hum Ecol Risk Assess 26 (6): 1603-1621.

Yidana SM, Banoeng-Yakubo B, Akabzaa TM (2010) Analysis of groundwater quality using multivariate and spatial analyses in the Ketabasin, Ghana. J Afr Earth Sci 58 (2): 220-234.

Zhang Y, Xu M, Li X, Qi J, Zhang Q, Guo J, Yu L, Zhao R (2018b) Hydrochemical Characteristics and Multivariate Statistical Analysis of Natural Water System: A Case Study in Kangding County, Southwestern China. Water 10 (1): 80.

\section{Tables}

Due to technical limitations the Tables are available as a download in the Supplementary Files.

\section{Figures}




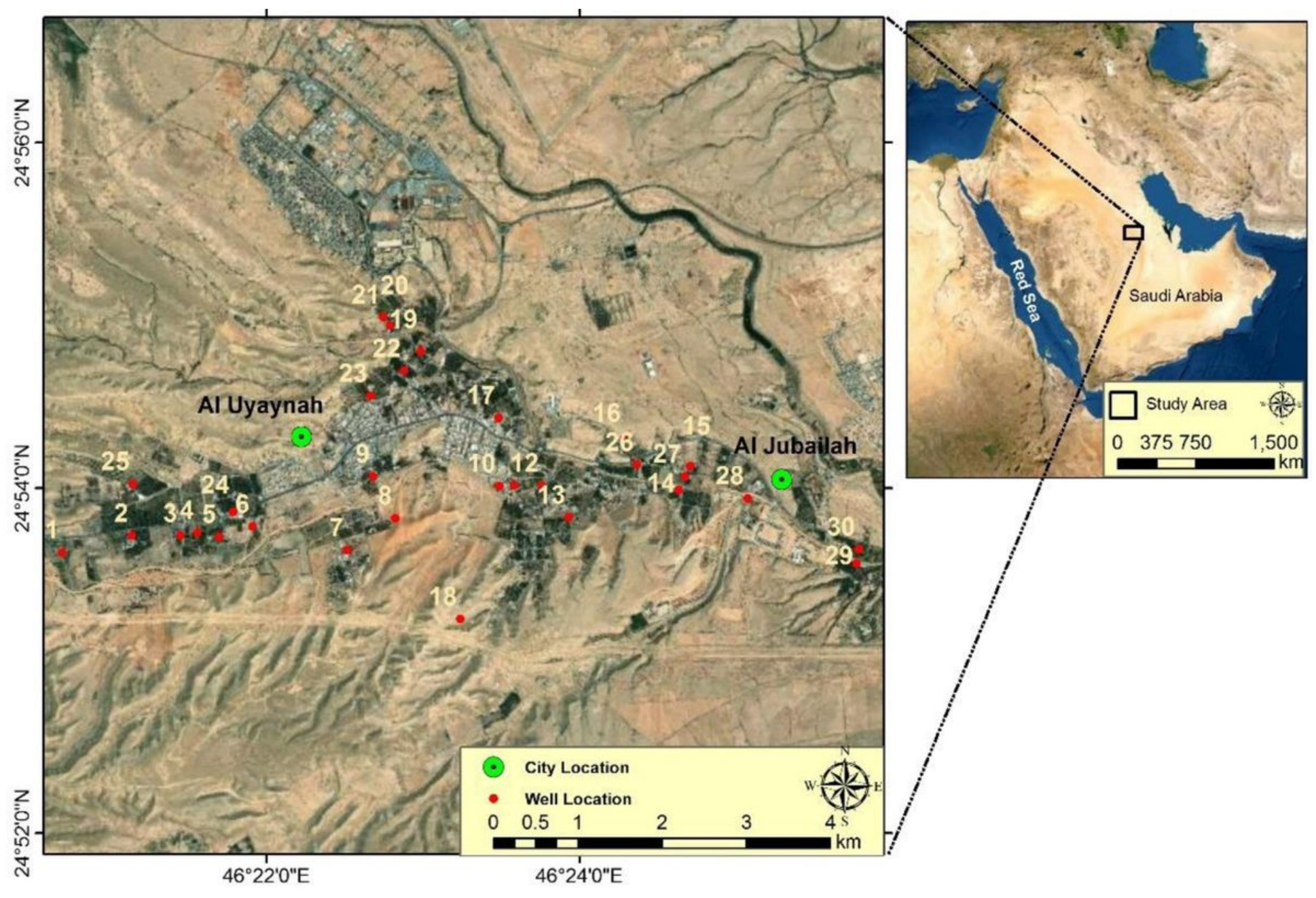

Figure 1

Location map of groundwater samples. 


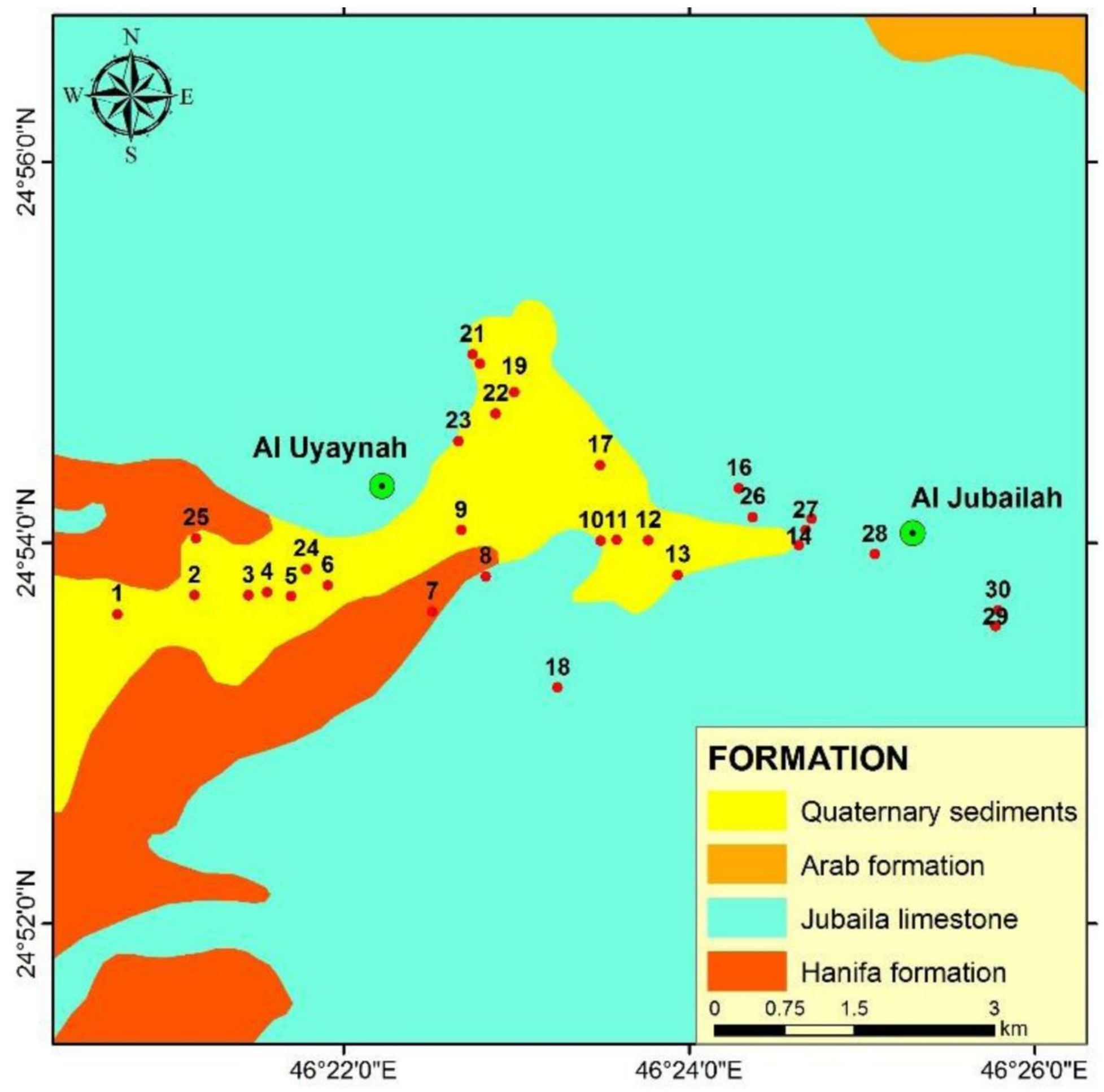

Figure 2

Geological map of the study area. 


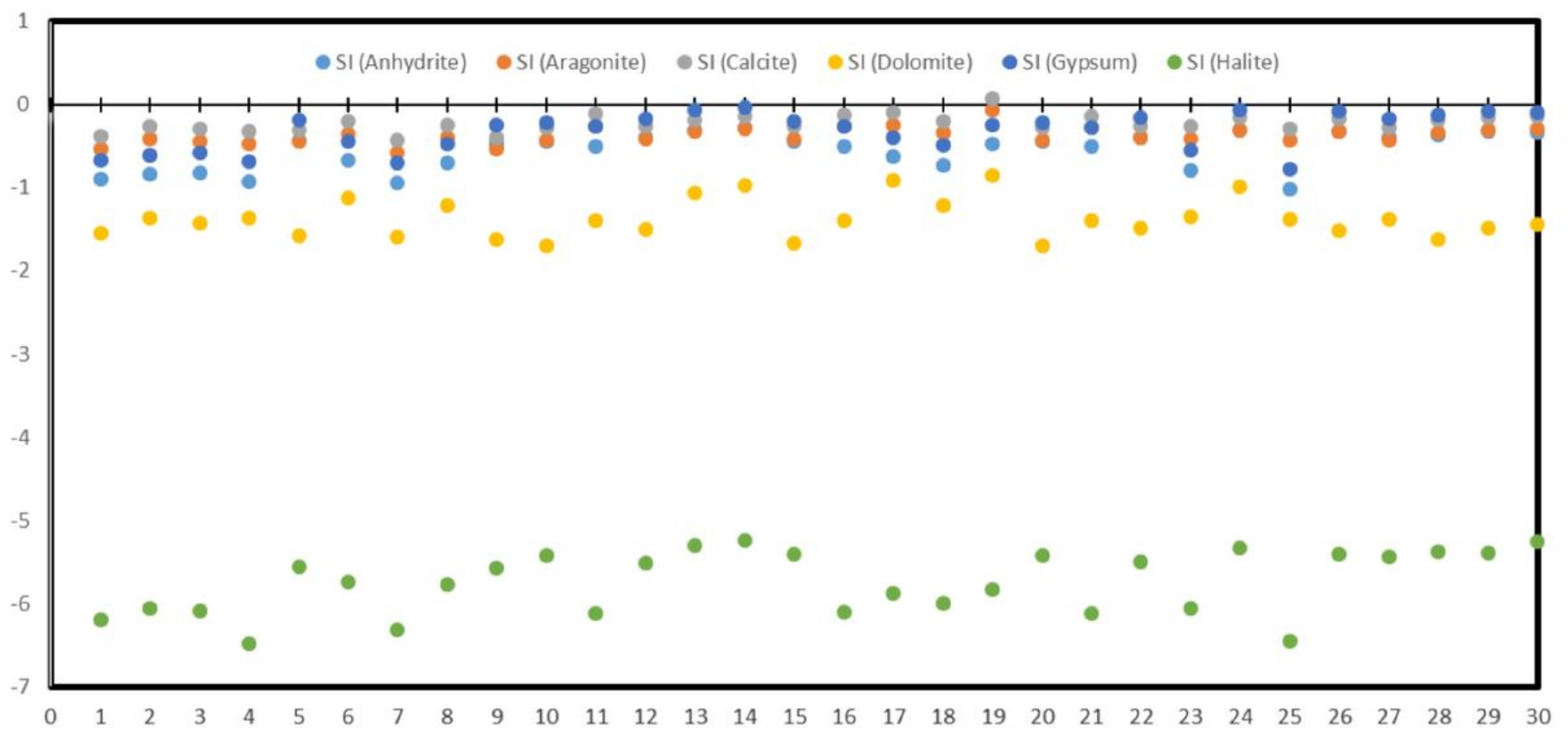

Figure 3

Saturation indices of the principal mineral phases in groundwater. 


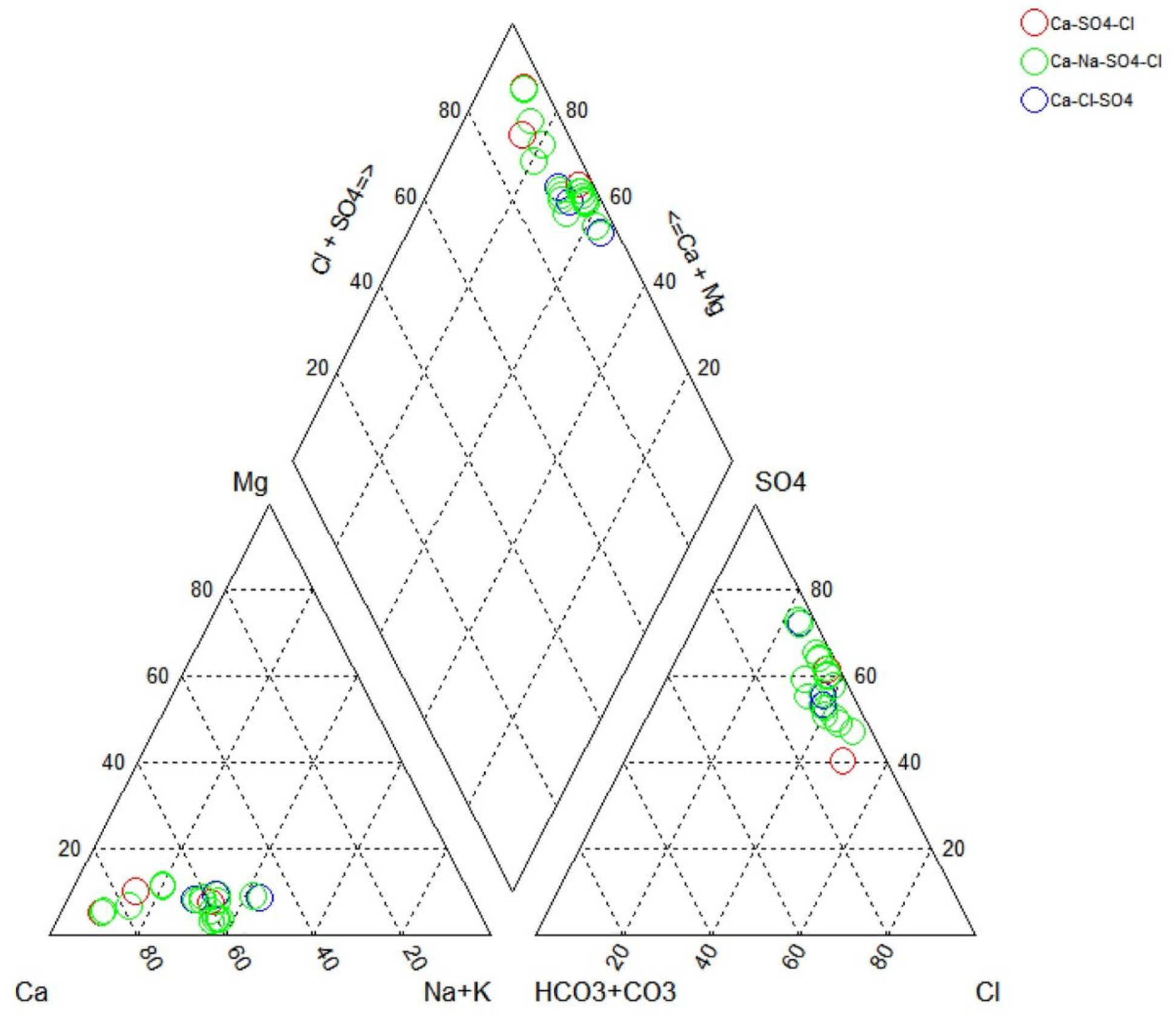

Figure 4

Classification of groundwater facies using the Piper diagram. 


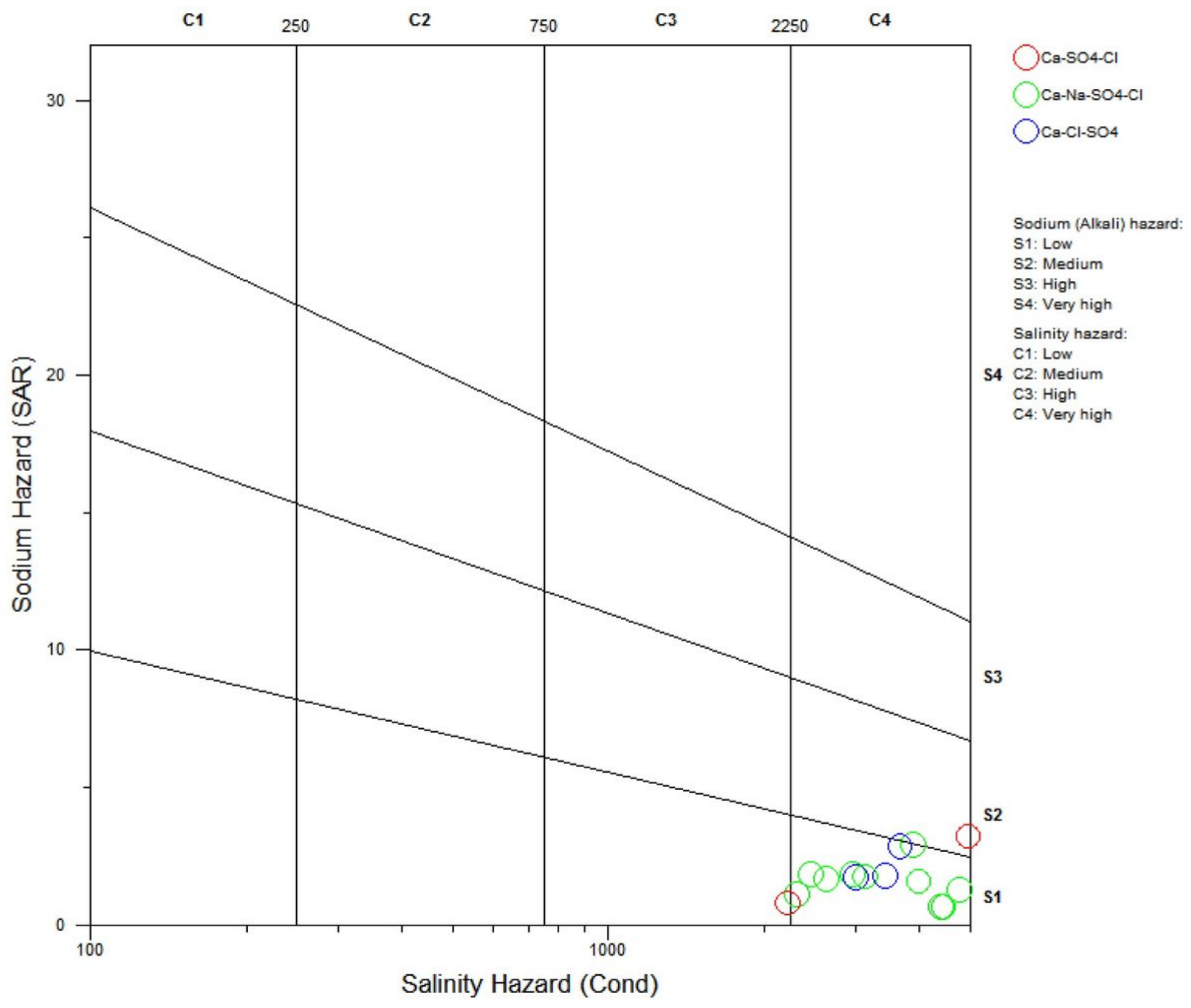

Figure 5

Classification of irrigation water using the Wilcox diagram. 


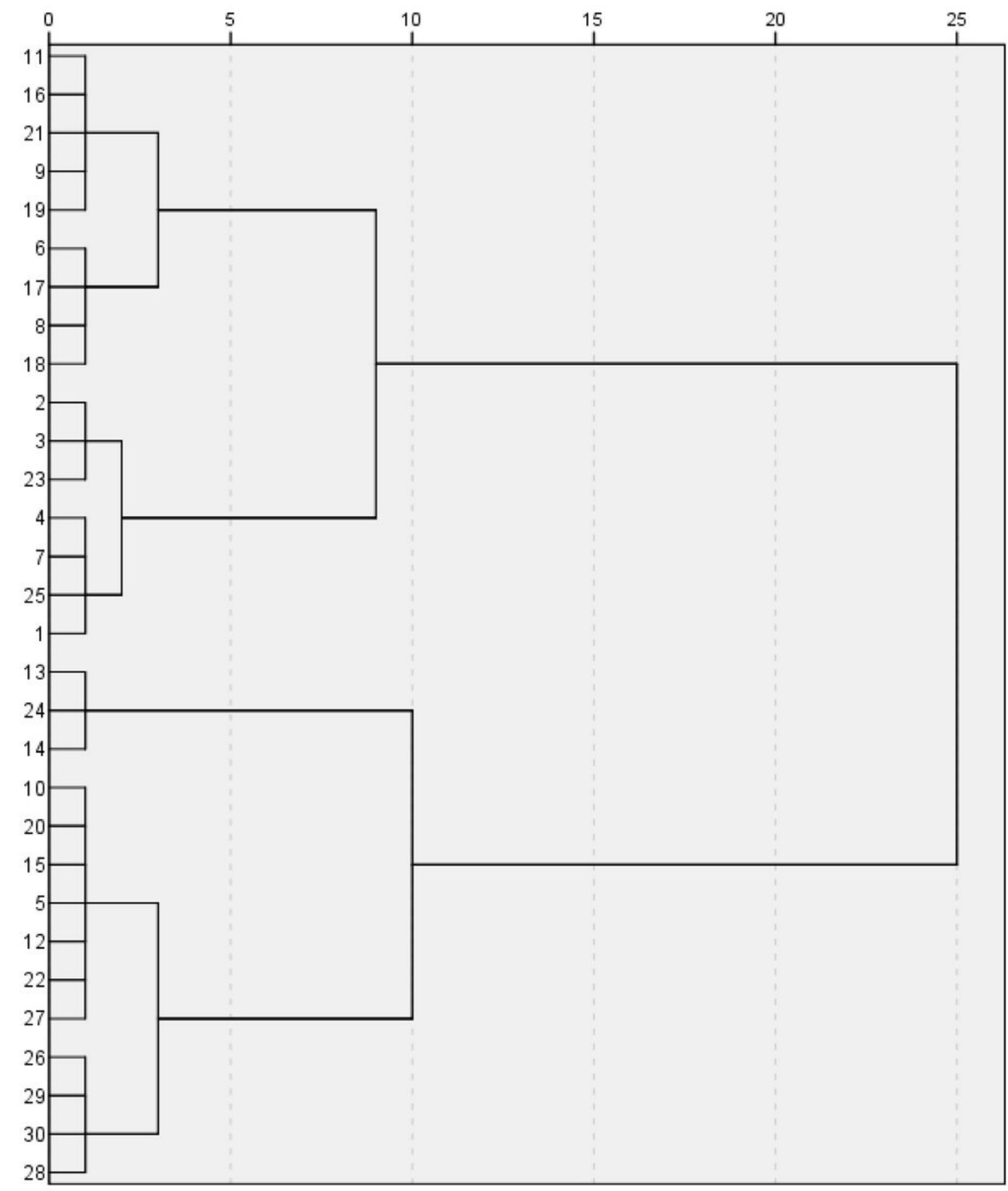

Figure 6

Q-mode HCA for groundwater samples. 


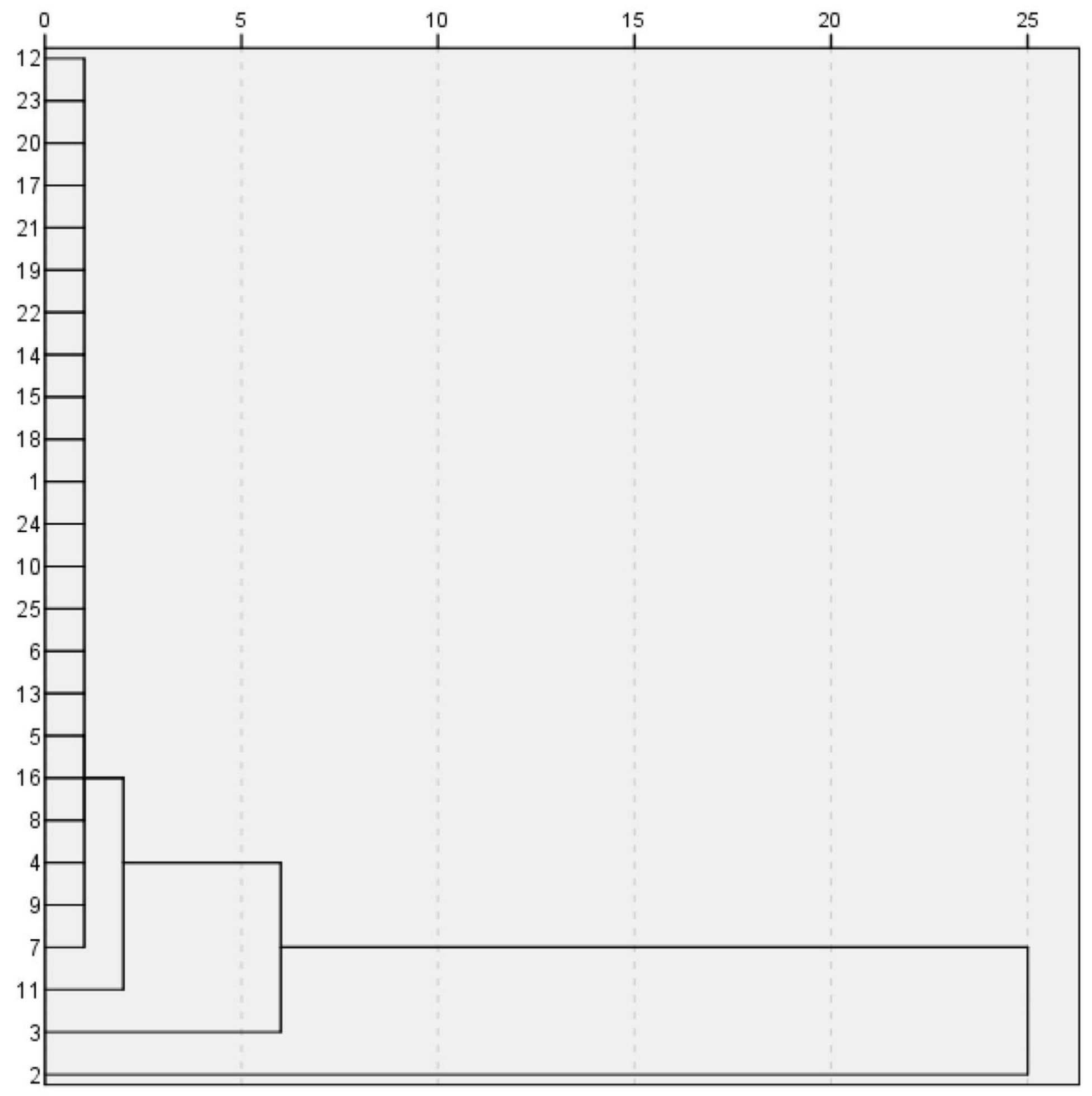

Figure 7

R-mode HCA dendrogram for the hydrogeochemical parameters in groundwater samples.

\section{Supplementary Files}

This is a list of supplementary files associated with this preprint. Click to download. 
- Tables.pdf

- SupplementaryMaterial.docx 